DOI: 10.46340/eujem.2021.7.1.13

Marharyta Chepeliuk, PhD in Economics

ORCID ID: https://orcid.org/0000-0002-1949-4747

Simon Kuznets Kharkiv National University of Economics, Ukraine

Andrii Hamiie

ORCID ID: https://orcid.org/0000-0002-4605-3410

Simon Kuznets Kharkiv National University of Economics, Ukraine

Roman Shkreben

ORCID ID: https://orcid.org/0000-0003-3325-2135

Simon Kuznets Kharkiv National University of Economics, Ukraine

Mykhailo Harnam

ORCID ID: https://orcid.org/0000-0002-7719-1971

Kyiv National University of Construction and Architecture, Ukraine

\title{
CURRENT STATE OF BUSINESS SPACE AND INDUSTRIAL ENTERPRISE DEVELOPMENT
}

The results of recent studies of the processes in domestic enterprises show the needs to focus attention on this issue in development research under conditions of high uncertainty, institutional constraints and the influence of stakeholder groups on strategic decision-making. From this perspective, the results of the analysis of the current state of industrial enterprises provide an information base for identifying development priorities and relevant tools for implementing relevant strategies. The proposed methodological approach to the complex analysis of the state and trends of the engineering industry enterprises includes the following sequence of stages: definition of the main idea of the study - the need to maintain the sustainability and protection against threats to the development of enterprises; the establishment of a system of criteria and indicators characterizing the economic security of enterprise development; the justification of economic mathematical modelling methods and estimation of factors of economic safety of enterprise development; interpretation of the results obtained. The analysis revealed that most of the industrial enterprises were pursuing a strategy of survival and financial stability in the short term after the investment had been withdrawn and production had been reduced. Only cluster 4 and cluster 2 enterprises are in need of policy measures related to the renewal of their organizational and productive activities and financial sustainability through the consolidation and movement of capital, savings and cost reduction, finding additional sources of income and improving assets. In accordance with the defined strategic guidelines, the fate of the relevant instrumental measures used by the selected enterprises was established: development strategies, organizational forms of integration, methods of organizational transformation, evaluation and analytical tools.

Key words: integrated analysis, economic condition, enterprise, development, informationanalytical tools.

Introduction. Trends in the development of the world machine-building industry show a deepening of specialization, cooperation and concentration, complications of production, improvement of qualification requirements of personnel. The most problematic issues and the readiness of the Ukrainian production sector for the future in terms of innovation and technology are: the low level of cluster development; the small percentage of enterprises that are ready to accept and introduce innovation in their production process; low levels of foreign direct investment and technology transfer and the introduction of information technologies. Domestic economic and investment activity has continued to decline, and industrial production in 2019 declined by $7.7 \%$ compared to 2018 year. At the same time, the rate of decline in mechanical engineering 
halves the overall decline in industry. Mechanical engineering in the industrial structure accounted for between 18 and $20 \%$ in 2013, and currently 7-8\%. On the basis of the analysis results states and prospects of development enterprises in the machine-building industry, it is determined that the production of machinebuilding products is being reduced (in 2019, compared to the previous year, there was a $5.6 \%$ drop in the level of production in mechanical engineering, $19.9 \%$ in the production of electrical equipment), and there was a low level of innovation of machine building enterprises; exports of machinery and imports declined in the main markets.

Problem Statement. To establish a methodological basis for a comprehensive analysis of the state and trends of industrial enterprises. Identify and substantiate strategic priorities for industrial development.

Results. For the study of the economic status and development processes of domestic engineering enterprises, the world trends of indirect (increased share of developing countries in the world economy, urbanization, growing economic globalization and interdependence of world market conditions, environmental issues) and direct (depletion of the raw material base, complications of transport and interorganizational links, growth of demand for high-tech products of mechanical engineering, and therefore the role of research and development and high-tech industries, meeting the requirements for the qualification of personnel, social responsibility of business) impacts ${ }^{1}$.

On the basis of the analysis results on domestic machine-building enterprises, it has been determined that for most of them (62\% of the enterprises among the subjects) under conditions of instability, the main strategic goal is to maintain financial and economic stability and consolidate their market position ${ }^{2}$. For example, among the 18 Kharkiv machine-building enterprises studied, most are pursuing a strategy to survive and maintain financial stability in the short term after the withdrawal of investments and the reduction of production. Only a quarter of the enterprises studied resolve issues related to the renewal of their organizational and productive activities. At the same time all machine-building enterprises are sensitive to the crisis conditions of the country economy. For the implementation of development strategies, the machinebuilding enterprises studied used such methods and forms of strategic partnership: cooperation with world high-tech companies (26.7\%); opening of branches and representative offices, including exclusive distribution agreements $(20 \%)$.

The analysis of investment-innovative, techno-technological, marketing and personnel management of the spheres of activity of the machine-building enterprises under study made it possible to identify the most problematic issues and peculiarities of the tools used to solve them. Thus, for the purpose of expanding the markets and promoting the brand by enterprises, the most relevant ones are: the use of rebranding tools (93.3\%); the use of external media for advertising campaigns (46.7\% of enterprises surveyed) the renewal of the trademark, logo, labelling and packaging (93.3\%); production and distribution of thematic souvenirs $(86.7 \%)$; and thematic press conferences $(13.3 \%)$; participation in fairs, conferences and exhibitions (100\%); preparation and posting of press releases for products; Regular publication of own electronic media $(66.7 \%)$ and so on.

The results of quality corporate management analysis on the machine-building enterprises studied showed that there are no clear criteria and procedures for assessing the personal contribution of each member of the supervisory board to the development of the enterprise; lack of a procedure for the selection and appointment of the members of the supervisory board on the basis of competence - $13 \%$ of the enterprises studied have no qualification requirements for the members of the supervisory board; among the requirements formed - in sectoral knowledge and work experience (47\% of enterprises), in personal qualities (46\% of enterprises), in financial and management knowledge ( $6 \%$ of enterprises studied), and in the absence of conflict of interest among the members of the supervisory board (5\% of enterprises examined $)^{3}$. This position of quality of corporate management in machine-building enterprises does not create conditions for competent strategic choice and defines the respective nature of the issues which make up ${ }^{4}$.

\footnotetext{
${ }^{1}$ Отенко, В. (2010). Стратегічний вибір підприємства та його реалізація. Харків: ІНЖЕК, 336; Воронков, Д. (2010). Управління змінами на підприємстві: теорія и прикладні аспекти. Харків: ІНЖЕК.

${ }^{2}$ Отенко, В. Погорелов, Ю. (2017). Модель розвитку підприємства як основа його стратегічного вибору. Бізнес-Інформ, 11, 448-453.

${ }^{3}$ Воронкова, А. Калюжна, Н. Отенко, В. (2008). Управлінські рішення у забезпеченні конкурентоспроможності підприємства: організаиійний аспект. Харків: ІНЖЕК, 427.

${ }^{4}$ Отенко, В., Доронін, С. (2018) Організаційне забезпечення формування професійних команд управлінського персоналу за допомогою соціоніки. Бізнес-інформ, 8, 217-224.
} 
The peculiarity of the action of the institute of strategic decision-making at machine-building enterprises is the high concentration of control and centralization of decisions by the management ${ }^{1}$. The fact that more than $53 \%$ of the enterprises surveyed do not submit to a joint-stock meeting discussions on strategic decisions is negative; they have a low degree of regulation of the activities of the administration; the main profits of large shareholders are obtained by managing the financial flows of the enterprise rather than as dividends; there is a lack of rules of dividend policy and irregular payment of dividends to shareholders; there is no internal audit service. More than half of the enterprises surveyed do not have their own research base, nor do they address issues related to innovative development - the development and mastery of new products or the improvement of the technical characteristics of existing ones.

The results of the comprehensive analysis form the basis for the formation of a methodical approach to the formation of the security-oriented development of enterprises in the mechanical engineering industry. Its stages are: the development of a system of criteria and indicators for the economic security of enterprise development; the justification of methods of economic and mathematical modelling and assessment of factors of economic security for enterprise development; interpretation of the results obtained.

The development of a set of indicators for analysing the state of development of industrial enterprises should be based on the resource approach, according to which the economic situation reflects: first of all, the provision of resources for the achievement of development goals through their efficient use in a volatile and volatile environment ${ }^{2}$. Groups of indicators were identified under this provision (table 1).

Table 1

\section{Set of indicators for identifying factors of economic security for enterprise development}

\begin{tabular}{|l|l|}
\hline \multicolumn{1}{|c|}{$\begin{array}{c}\text { Criteria for the distribution } \\
\text { of indicators by group }\end{array}$} & \multicolumn{1}{c|}{ Indicators } \\
\hline $\begin{array}{l}\text { Financial sustainability, } \\
\text { performance and business } \\
\text { performance }\end{array}$ & $\begin{array}{l}\text { Ratios: autonomy, manoeuvrability of equity, total coverage, absolute } \\
\text { and critical liquidity, solvency, turnover of receivables and payables; } \\
\text { fixed asset index } \\
\text { Profitability: assets, equity, products sold, productive assets; } \\
\text { Rate of change: sales, assets, net profit, share of production assets }\end{array}$ \\
\hline $\begin{array}{l}\text { The state of innovation and } \\
\text { investment activity }\end{array}$ & $\begin{array}{l}\text { Rate of change: gross investment in fixed capital, the share of investment } \\
\text { in capital construction, investment in the acquisition of fixed assets, the cost } \\
\text { of technological innovation, the cost of informatization, software costs }\end{array}$ \\
\hline The state of production potential & $\begin{array}{l}\text { Rate of change: share of capital stock in productive capacity, share } \\
\text { of production stocks in productive capacity, share of uncompleted production } \\
\text { in productive capacity, share of fixed assets in assets, consumption of capital } \\
\text { stock, Income and disposals of plant and equipment, productivity, stock } \\
\text { and fund performance }\end{array}$ \\
\hline The state of human resources & $\begin{array}{l}\text { Factors: turnover of staff, recruitment, turnover upon attrition; training } \\
\text { for new occupations; retraining of existing staff, staff development, rate } \\
\text { of growth of regular staff }\end{array}$ \\
\hline
\end{tabular}

\section{Source: formed by the authors on the basis ${ }^{3}$}

It should be noted that the proposed set of indicators avoids subjectivity in the results obtained, is simple and accessible, and makes it possible to establish clear fixed boundaries between the different conditions of the enterprise. However, the method of factor stochastic analysis (main component method) is useful for identifying latent factors as a result of the factor analysis carried out on the economic status of the Kharkiv region's machine-building enterprises under study, 10 factors have been identified in five years, the structure of which is shown in table 2.

\footnotetext{
${ }^{1}$ Отенко, В., Стоказ, Я. (2018). Методичний підхід до оцінювання стратегічних знань підприємства. Науковий вісник Полтавського університету економіки і торгівлі, 2 (87), 49-57.

2 Пономаренко, В., Клебанова, Т. (ред.) (2019). Инструментальные средства моделирования систем в информационной экономике. Харків: ВШЕМ ХНЭУ им. С. Кузнеца, 452.

${ }^{3}$ Отенко, І., Комарков, Д., Шкребень, Р. (2018). Стратегічний інструментарій безпеко-орієнтованого розвитку підприємства. Проблеми економіки, 2, 235-241.
} 


\section{Factors of economic security of the development of machine-building enterprises of the Kharkiv region}

\begin{tabular}{|c|c|}
\hline $\begin{array}{l}\text { Symbol and name } \\
\text { of the factor }\end{array}$ & Linear equations of identified factors \\
\hline \multirow[b]{2}{*}{$\mathrm{F}_{1--}$ financial stability } & $\begin{array}{c}\mathrm{F}_{1}=0,924 \mathrm{x}_{3}+0,907 \mathrm{x}_{2+} 0.885 \mathrm{x}_{5}+0,864 \mathrm{x}_{2} 8-0,864 \mathrm{x}_{9}+0,827 \mathrm{x}_{4}+ \\
+0,632 \mathrm{x}_{13}+0,515 \mathrm{x}_{1}\end{array}$ \\
\hline & $\begin{array}{c}\mathrm{x}_{3} \text { - total funded ratio; } \mathrm{x} 2 \text { - equity manoeuvrability ratio; } \\
\mathrm{x} 5 \text { - critical liquidity ratio; } \mathrm{X} 28 \text { - capital performance ratio; } \\
\text { x9 - fixed asset index } \mathrm{x} 4 \text { - absolute liquidity ratio; } \\
\mathrm{x} 13 \text { - rate of return on productive assets; } \mathrm{x} 1 \text { - rate of autonomy }\end{array}$ \\
\hline \multirow{2}{*}{$\begin{array}{l}\mathrm{F}_{2}-\text { efficiency of investment } \\
\text { and innovation activities }\end{array}$} & $\mathrm{F}_{2}=0,962 \mathrm{x}_{35}+0,962 \mathrm{x}_{38}+0,810 \mathrm{x}_{7}$ \\
\hline & $\begin{array}{l}\mathrm{x}_{35} \text { - rate of growth of gross fixed investment; X38 - rate of growth of costs } \\
\text { of technological innovation; } 7 \text { - rate of growth of turnover of payables }\end{array}$ \\
\hline \multirow{2}{*}{$\begin{array}{l}\mathrm{F}_{3}-\text { rate of renewal } \\
\text { of staff capacity and productive } \\
\text { assets }\end{array}$} & $\mathrm{F}_{3}=0,820 \mathrm{x}_{29}+0,687 \mathrm{x}_{24}+0,426 \mathrm{x}_{34}$ \\
\hline & $\begin{array}{l}\text { X29 - the turnover factor after recruitment; } x 24 \text { - the intake factor } \\
\text { of fixed assets; } x 34 \text { - the growth factor of regular staff. }\end{array}$ \\
\hline \multirow[b]{2}{*}{$\begin{array}{l}\mathrm{F}_{4}-\text { adequacy of productive } \\
\text { capacities }\end{array}$} & $\mathrm{F}_{4}=0,863 \mathrm{x}_{17}+0,819 \mathrm{x}_{21}+0,512 \mathrm{x}_{15}$ \\
\hline & $\begin{array}{l}\text { x17 - the growth rate of the share of productive assets of an enterprise; } \\
\text { x21 - the growth rate of productive capacity; } \\
\text { x15 - the growth rate of an enterprise's assets. }\end{array}$ \\
\hline \multirow{2}{*}{ F5 - efficiency of activity } & $\mathrm{F} 5=0,932 \times 12+0,929 \times 11$ \\
\hline & $\begin{array}{l}\text { x12 - profitability coefficient of sales; } \\
\text { x11 - profitability coefficient of equity. }\end{array}$ \\
\hline \multirow{2}{*}{$\begin{array}{l}\text { F6 - rationalization } \\
\text { of asset structure }\end{array}$} & $\mathrm{F} 6=0,887 \times 22+0,716 \times 8+0,670 \times 25$ \\
\hline & $\begin{array}{l}\text { x22 - growth factor of fixed assets in assets; } x 8-\text { growth factor } \\
\text { of accounts receivable; } x 25 \text { - loss of fixed assets. }\end{array}$ \\
\hline \multirow{2}{*}{$\begin{array}{l}\text { F7 - efficiency in the use } \\
\text { of capital assets }\end{array}$} & $\mathrm{F} 7=0,806 \times 23-0,687 \times 30+0,441 \times 18$ \\
\hline & $\begin{array}{l}\text { x23 - turnover rate after retirement; x30 - consumption rate of capital stock; } \\
\text { x18 - growth rate of capital stock in productive capacity. }\end{array}$ \\
\hline \multirow{2}{*}{$\begin{array}{l}\mathrm{F}_{8}-\text { availability of qualified } \\
\text { personnel }\end{array}$} & $\mathrm{F}_{8}=0,741 \mathrm{x}_{36}+0,706 \mathrm{x}_{33}+0,478 \mathrm{x}_{31}$ \\
\hline & $\begin{array}{c}\text { x36 - capital investment rate growth rate; x33 - staff development rate; } \\
\text { x31 - training rate for new professions. }\end{array}$ \\
\hline \multirow{2}{*}{$\begin{array}{l}\mathrm{F}_{9}-\text { productive capacity } \\
\text { functionality }\end{array}$} & $F_{9}=0,612 x_{10}-0,833 x_{20}$ \\
\hline & $\begin{array}{l}\mathrm{x} 10 \text { - the rate of return on assets; } \mathrm{x} 20 \text { - the rate of increase the share } \\
\text { of work-in-progress }\end{array}$ \\
\hline \multirow{2}{*}{$\mathrm{F}_{10}-$ business activity } & $\mathrm{F}_{10}=0,734 \mathrm{x}_{14}-0,621 \mathrm{x}_{28}$ \\
\hline & 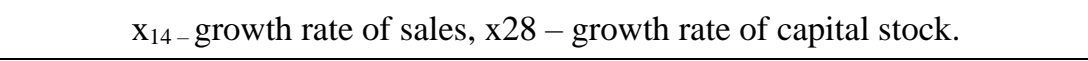 \\
\hline
\end{tabular}

Source: formed by the authors on the basis ${ }^{l}$

\footnotetext{
${ }^{1}$ Отенко, В., Отенко, І. (2009). Аналітичний аспект прийняття стратегічних рішень. Ліберманівські читання: економічна спадщина та сучасні проблеми. Харків: Лібуркіна Л.М.; ІНЖЕК, 211-225.
} 
Factors of $80.85 \%$ have been identified to explain the current level of economic condition of the machine-building enterprises under investigation. The sequence of indicators in systems of linear equations corresponds to the extent of their influence on the overall level of the factor, starting with the maximum. Thus, financial sustainability (F1) accounts for $18.45 \%$ of the variability of the system of indicators, that is, its impact on the overall level of economic performance is fundamental. As can be seen from the structure of the factor (table 2), the main factors influencing this factor are: total coverage (x3), manoeuvrability of equity (x2) and critical liquidity (x5). However, it cannot be argued that the fact that these indicators have entered the system of linear equations with the sign «+» as they grow increases and the overall level of the factor positively influences the state of economic safety of machine-building enterprises. For these indicators, the normative values of change (decrease or exceeding) are defined, which indicate the threat of a loss of financial sustainability of the enterprise. Thus, it is possible to identify several zones reflecting the state of this factor determining the financial sustainability of the enterprise. If the values of liquidity are within the range of regulatory values that are recommended, it indicates an "excellent" financial and economic condition of the enterprise, which implies security conditions for the development of the enterprise. The constant asset index has a negative impact among certain components and has a weight of -0.864 (table. 2) and shows the proportion of immobilized assets in equity. This indicates that the enterprises under study are characterized by a low level of non-current renewal, which significantly reduces the mobility of the enterprise and its ability to respond in a timely manner to changes in the external environment.

The investment innovation efficiency factor (F2) accounts for $13.3 \%$ variability in the economic performance of the enterprises studied. This factor is formed by the indicators-promoters: the rate of growth of gross fixed investment, the rate of growth costs for technological innovation, the rate of growth turnover for payables. The growth of gross fixed investment has a strong influence among certain components. this demonstrates the potential for development through investment in modernization, restructuring or other organizational changes ${ }^{1}$.

The enterprise resource renewal intensity factor (F3) describes the process of updating the enterprise's human and technical potential. Despite the positive impact of the indicators that comprise it, it is necessary to analyse the trends in these indicators, as the increase in the number of regular staff (x34) and the turnover of staff after recruitment (X29) has increased can be extensive and indicative of turnover. At the same time, a combination of factors should be considered of the availability of skilled personnel (F8), as the staff development index (x33) has a positive impact.

Factors supporting the case for sustainability in enterprise development are: sufficiency of productive capacity (F4), performance (F5), asset structure and rationality (F6). However, it can be assumed that a number of challenges remain in the innovation processes of enterprises and the growth of technological capabilities. This conclusion is supported by the structure of factors - capital use efficiency (F7), productive capacity functionality (F9) and business (F10).

However, the selected enterprises have different value levels for the factors identified, so a scientifically sound classification of enterprises is warranted. Statistical homogeneity can be distinguished by various multidimensional statistical methods. The cluster analysis method is the most appropriate to the task. This choice is justified by the fact that cluster analysis methods do not require information on the numbers and characteristics of possible clusters.

An input system of indicators for cluster analysis of the identified economic factors of the 18 enterprises studied, based on the main component method (Table. 1). To distinguish the number of enterprise groups, it was assumed that there were three clusters - enterprise groups. Separated enterprise (part of a one-element cluster) - PJSC "Turboatom" are specific because they act as a monopolist and have an impact on the development of the industry in the country and in the world in the engineering market (Table 3).

Thus, most of the industrial enterprises are pursuing a strategy of survival and financial stability in the short term, once investment has been removed and production has been reduced. Only cluster 4 and cluster 2 enterprises are in need of policy measures related to the renewal of their organizational and productive activities and financial sustainability through the consolidation and movement of capital, savings and cost reduction, finding additional sources of income and improving assets. At the same time all machine-building enterprises are sensitive to the crisis conditions of the economy of the country.

\footnotetext{
${ }^{1}$ Malyarets, L. Otenko, I. (2019). Modeling of export-import potential. MODERN MANAGEMENT REVIEW. $M M R, X X I V, 26(3), 51-61$.
} 


\section{Development strategies by clusters of researched enterprises}

\begin{tabular}{|c|c|}
\hline Enterprises & $\begin{array}{l}\text { Description and development strategy tools } \\
\text { for selected clusters }\end{array}$ \\
\hline $\begin{array}{c}\text { IV cluster: } \\
\text { OJSC «Electromachina», } \\
\text { OJSC «Turbogaz» }\end{array}$ & $\begin{array}{l}\text { The cluster consists of enterprises that work steadily and pay attention } \\
\text { to staff development. External and internal growth strategies are being } \\
\text { implemented through the adoption and implementation of decisions } \\
\text { to expand the range of products and to reach external markets. } \\
\text { It is characterised by average earnings, high fund performance } \\
\text { and productivity. }\end{array}$ \\
\hline $\begin{array}{c}\text { III Cluster : } \\
\text { PJSC "Ukrelectromash HELS", } \\
\text { PJSC "HARVERST", } \\
\text { PJSC "Kharkiv Plant of Stamps and } \\
\text { Molds", } \\
\text { PJSC "Tochprilad", } \\
\text { PJSC "Experimental Electrical Plant", } \\
\text { PJSC "HVZ", } \\
\text { PJSC "Lozovsky Traktorodetal Plant", } \\
\text { PJSC "Kharkiv Machine-Building } \\
\text { Plant" Plinfa "", } \\
\text { PJSC "Kupyansk Machine-Building } \\
\text { Plant", } \\
\text { PJSC "Hartron" }\end{array}$ & $\begin{array}{l}\text { It can be characterized as a group of medium- and small-scale enterprises } \\
\text { with development potential. A survival strategy based on financial } \\
\text { soundness is being implemented. Solving problems by taking decisions } \\
\text { on consolidation and movement of capital, saving, reducing costs, finding } \\
\text { additional sources of income, reducing assets for recovery. Enterprises } \\
\text { have insignificant returns and losses. In this cluster of enterprises there } \\
\text { are low rates of fund return and profitability, marketing activity. }\end{array}$ \\
\hline $\begin{array}{c}\text { II cluster: } \\
\text { PJSC "Plant. Frunze », } \\
\text { PJSC "HTZ them. Ordzhonikidze ", } \\
\text { PJSC "HARP", } \\
\text { PJSC "Pivdenkabel Plant", } \\
\text { FED Machine-Building Plant }\end{array}$ & $\begin{array}{l}\text { This cluster covers sufficiently developed and competitive enterprises } \\
\text { with a significant market share. These enterprises, despite the impact } \\
\text { of negative externalities, were the least sensitive to structural changes } \\
\text { in the market, imbalances, currency fluctuations, and so on. They use } \\
\text { a strategy of internal growth through decisions on product renewal } \\
\text { and market expansion, search for new markets, training of company } \\
\text { personnel, restructuring of production capacities. Enterprises are } \\
\text { characterized by low returns and satisfactory costs per } 1 \text { UAH. } \\
\text { Products have a high turnover level and a significant material content } \\
\text { of production. Overall, it can be argued that two clusters rank second } \\
\text { in terms of performance. }\end{array}$ \\
\hline I cluster (PJSC "Turboatom") & $\begin{array}{l}\text { It can be argued that the enterprise has influence on the development } \\
\text { of the industry in the country and in the world in the market } \\
\text { of mechanical engineering. Despite the difficult financial and economic } \\
\text { situation in the country, the enterprise remains profitable, adheres } \\
\text { to the strategy of «no change», as it is a monopolist. The enterprise is } \\
\text { the most important in terms of numbers of employees, earnings per } \\
\text { employee, profitability, liquidity and financial independence. }\end{array}$ \\
\hline
\end{tabular}

Source: formed by the authors on the basis ${ }^{l}$

Conclusions. According to the defined strategic guidelines, the share of relevant instrumental measures used by enterprises that have chosen development strategies - passive survival (63\%), active survival (50\%), active impact on the environment (31\%); organizational forms of integrationcorporatization of business $(56 \%)$, cooperation and strategic alliances $(75 \%)$, business narrowing (44\%); methods of organizational transformation - reorganization (38\%), restructuring (63\%), reengineering (32\%), reconstruction $(50 \%)$, redevelopment $(6 \%)$; evaluation and analytical tools - forecasting $(75 \%)$, strategic analysis and accounting (63\%), controlling (75\%), consulting (25\%), benchmarking (69\%), coaching (13\%), risk assessment methods (88\%) ). The results of the analysis together allow to improve the methodological tools of strategic management of industrial enterprises.

\footnotetext{
${ }^{1}$ Отенко І., Чепелюк М. (2016). Стратегічні заходи формування корпоративної культури в процесі організаційних змін підприємства. Глобальні та національні проблеми економіки, 10, 443-446.
} 


\section{References:}

1. Otenko, V. (2010). Stratehichnyi vybir pidpryiemstva ta yoho realizatsiia [Strategic choice of the enterprise and its realization]. Kharkiv: INJEK. [in Ukrainian].

2. Voronkov, D. (2010). Upravlinnia zminamy na pidpryiemstvi: teoriia y prykladni aspekty [Enterprise change management: theory and applied aspects]. Kharkiv: INJEK. [in Ukrainian].

3. Otenko, V., Pohorelov, Yu. (2017). Model rozvytku pidpryyemstva yak osnova yoho stratehichnoho vyboru [The model of enterprise development as the basis of its strategic choice]. Biznes-Inform [Business-Inform], 11, 448-453. [in Ukrainian].

4. Voronkova, A., Kaliuzhna, N., Otenko, V. (2008). Upravlinski rishennia u zabezpechenni konkurentospromozhnosti pidpryiemstva: orhanizatsiinyi aspekt [Management decisions in ensuring the competitiveness of the enterprise: organizational aspect]. Kharkiv: INJEK. [in Ukrainian].

5. Otenko, V., Doronin, S. (2018). Orhanizatsiine zabezpechennia formuvannia profesiinykh komand upravlinskoho personalu za dopomohoiu sotsioniky [Organizational support for the formation of professional management teams with the help of socionics]. Biznes-inform [Business-Inform], 8, 217-224. [in Ukrainian].

6. Otenko, V., Stokaz, Yu. (2018). Metodychnyi pidkhid do otsiniuvannia stratehichnykh znan pidpryiemstva [Methodical approach to the assessment of strategic knowledge of the enterprise]. Naukovyi visnyk Poltavskoho universytetu ekonomiky i torhivli [Scientific bulletin of poltava university of economics and trade], 2 (87), 49-57. [in Ukrainian].

7. Ponomarenko, V., Klebanova, T. (ed.) (2019). Instrumentalnye sredstva modelirovaniia sistem v informatcionnoi ekonomike [Tools for modeling systems in the information economy]. Kyiv: VShEM. [in Russian].

8. Otenko, I., Komarkov, D., Shkreben, R. (2018). Stratehichnyi instrumentarii bezpeko-oriientovanoho rozvytku pidpryiemstva [Strategic tools for security-oriented enterprise development]. Problemy ekonomiky [Problems of the economy], 2, 235-241. [in Ukrainian].

9. Otenko, V., Otenko, I. (2009). Analitychnyi aspekt pryiniattia stratehichnykh rishen [Analytical aspect of strategic decision making]. Libermanivski chytannia:ekonomichna spadshchyna ta suchasni problemy [Lieberman readings: economic heritage and modern problems]. Kharkiv: INJEK. [in Ukrainian].

10. Malyarets, L., Otenko, I. (2019). Modeling of export-import potential. Modern Management Review. MMR, XXIV, 26 (3). Kharkiv: INJEK, 51-61. [in English].

11. Otenko, I., Chepeliuk, M. (2016). Stratehichni zakhody formuvannia korporatyvnoi kultury v protsesi orhanizatsiinykh zmin pidpryiemstva [Strategic measures for the formation of corporate culture in the process of organizational change of the enterprise]. Hlobalni ta natsionalni problemy ekonomiky [Global and national economic problems], 10, 443-446. [in Ukrainian]. 